\title{
Effect of Irrigation with Brackish Water on the Morpho-Biochemical Behavior of Olea Europaea
}

\author{
Gharabi Dhia $^{1,}$, , Benchaben Hellal ${ }^{2}$, Abdelkrim Hassani ${ }^{1}$ \\ ${ }^{1}$ Laboratory of Agro Biotechnology and Nutrition in Dry Areas, Ibn Khaldoun University, Tiaret, Algeria \\ ${ }^{2}$ Laboratory of Geomatics and Sustainable Development, Ibn Khaldoun University, Tiaret, Algeria
}

\section{Email address:}

gharabidhia@yahoo.fr (G. Dhia)

${ }^{*}$ Corresponding author

\section{To cite this article:}

Gharabi Dhia, Benchaben Hellal, Abdelkrim Hassani. Effect of Irrigation with Brackish Water on the Morpho-Biochemical Behavior of Olea Europaea. Ecology and Evolutionary Biology. Vol. 3, No. 3, 2018, pp. 20-26. doi: 10.11648/j.eeb.20180303.11

Received: October 30, 2018; Accepted: November 26, 2018; Published: December 24, 2018

\begin{abstract}
The objective of this work is to determine the morpho-biochemical behavior of olive ( 2 years old) plants stemming from herbaceous cuttings and grafted on an oleaster, with two varieties of Spanish origin (Manzanilla and Arbiquina) and two varieties of Algerian origin (Sigoise and Chemlal) under the effect of irrigation with salin water at $100 \mathrm{mM}-1-1 \mathrm{NaCl}$. The experimentation takes place in the Faculty of Science of Nature and Life - Tiaret Ibn Khaldoun - University - Algeria, under a semi-automatic greenhouse and under well controlled conditions. The control plants are irrigated with a nutrient solution, while the plant stress received nutrient solution enriched by sodium chlorure in four repetitions $100 \mathrm{mM} / 1 \mathrm{NaCl}$. The analysis focused on the measurement of leaf area, soluble sugar and proline content. According to the results obtained, the leaf area of the treated plants slightly decreased compared to that of the control plants. However, the 20 weeks of brackish irrigation resulted in proline and sugars accumulation in the stressed genotype compared to the control genotype. In addition, this accumulation is very important for the leaves of plants local origin (Algerian) compared to introduced plants (Spanish) and in the leaves of plants grafted on oleaster compared to plants from herbaceous cuttings.
\end{abstract}

Keywords: Olive Trees, Herbaceous Cuttings, Grafted, Salt Stress, Proline, Sugars and Leaf Area

\section{Introduction}

The olive tree "Olea europaea L. ssp europaea" is a symbolic and distribute tree in the Mediterranean flora for thousands of years in the wild (sylvestris var.) or cultivated (europaea variety). It is renowned for its great hardiness, allowing it to develope and grow under conditions of sub-climate and sometimes very poor soil. It perfectly supports drought [1].

Indeed, the development of olive growing in the Mediterranean and Algeria has been the subject of a vast development program focusing on quantity and quality.

However, sanility of soil and irrigation water compromises the cultivation of olive trees in some areas [2, 3]. This sanility is mainly anthropogenic (excessive use of chemical inputs and repeated irrigation with brackish water without dryning) [4, 5]. It is to be noted that in the ecosystem, marked by severe and frequent droughts, salinization of soils is one of the main factors limiting the development of plants. About 15 million hectares of agricultural land are subject to increasing sanility [6]. The aim of this work is to determine the effect of salinity on the morphological and biochemical behavior of the leaves of four genotypes of olives. They are obtained from herbaceous cuttings and grafted on the oyster, including two genotypes of Algerian origin (Chemlal and Sigoise) and two Spanish origins. (Manzanilla and Arbiquina). They are irrigated with brackish water at $100 \mathrm{mM} \mathrm{NaCl}$. The study parameters are the measurement of the height of the leaves, the quantification of proline and the soluble sugars of the four genotypes.

\section{Material and Methods}

The experiment is carried out at Ibn-Khaldoun University in Tiaret, Algeria, under a greenhouse in a controlled environment with a daytime temperature of $18^{\circ} \mathrm{C}$ and a nighttime temperature of $10^{\circ} \mathrm{C}$, a relative humidity of $70 \%$ and a photoperiod of 10-12 h; on 2-year-old olive trees placed in pots of 40 centimeters in diameter and 50 
centimeters in length containing a substrate (consisting of four volumes of sand, one (1) volume of soil and one volume of organic matter or manure). The study is conducted in blocks with four repetitions.

The experimentation is carried out on two genotypes stemming from herbaceous cuttings and grafted on the local oleaster (Sigoise and Chemlal) (Algeria) and two others of Spanish origin (Manzanilla and Arbiquina).

After 90 days of adapt each seedling received a standardized and balanced nutrient solution such as [7]. The treated plants were sprayed with the nutrient solution and twice a week with $300 \mathrm{ml}$ of $100 \mathrm{mM} \mathrm{NaCl}$ solution. Control plants received only the nutrient solution. Analyzes and measurements were performed after 20 weeks of salt stress.

\subsection{Leaf Area}

The surface of excised leaves (SF) is measured using a LICOR-3000A electronic planimeter. This last takes the length and width of the sheet. The area is then calculated with the following formula [8]:
L.A $\left(\mathrm{cm}^{2}\right)=\mathrm{L}(\mathrm{cm}) \times \ell(\mathrm{cm}) \times \mathrm{k} ;[\mathrm{k}=0,72]$.
L: Length
$\ell$ : width

\subsection{Determination of the Soluble Sugars}

The dosage of the soluble sugars is carried out according to the method of [9] used by [10].

\subsection{Determination of Proline Content}

The proline assay is performed according to the method of [11] and improved by Lahrer and Magnecité by [12].

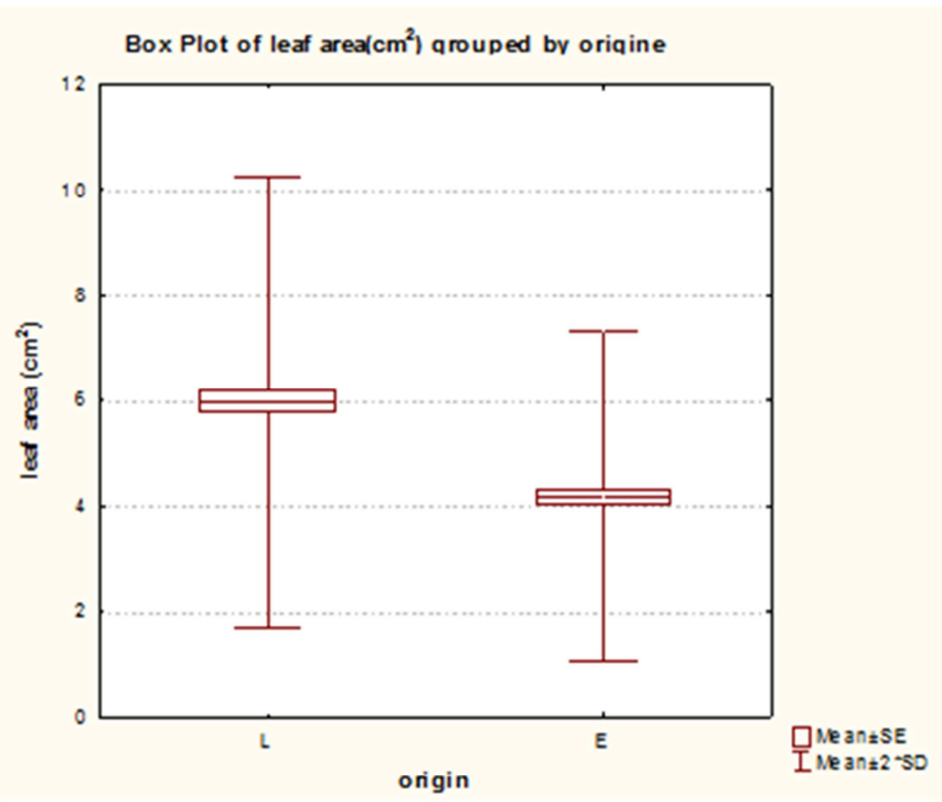

(a)

\subsection{Statistical Analysis}

The results of the experiment are processed with Statistical Software (Stat32.exe, Version 8.0). They are subject to a three-way analysis of variance. The values of the link between the study parameters are recorded in a correlation matrix.

The arithmetic mean of the twelve repetitions is calculated with a $5 \%$ confidence interval.

\section{Results}

The leaf area: Our statistical results are significant (Table.1) for the effect of the origin and the effect of the salt on the leaf surface and not important for the effect of the type of plant (threshold of the bit error rate of 5\%). Indeed, it shows that after twenty weeks of treatment with $100 \mathrm{mM} . \mathrm{l}^{-1}$ $\mathrm{NaCl}$, most of the genotypes studied did not show marqued decrease in leaf area. The reduction in leaf area of all the plants tested ranged from 0.94 to $1.14 \mathrm{~cm} 2$ compared with the control (Figure 1a).

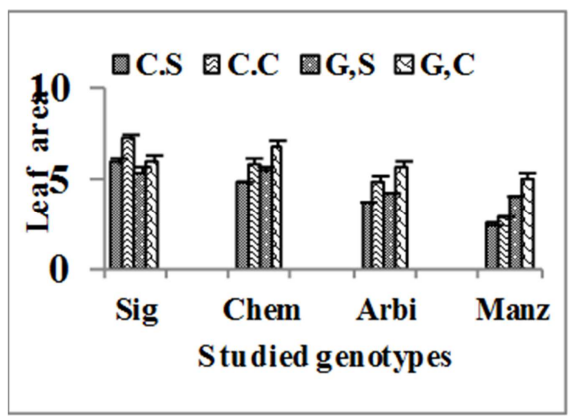

Figure 1. Leaf area $\left(\mathrm{cm}^{2}\right)$ of the studied olive plants SC: stressed cuttings, CC: Cutting Control, SG: Stressed Graft, GC: Grafted Control).

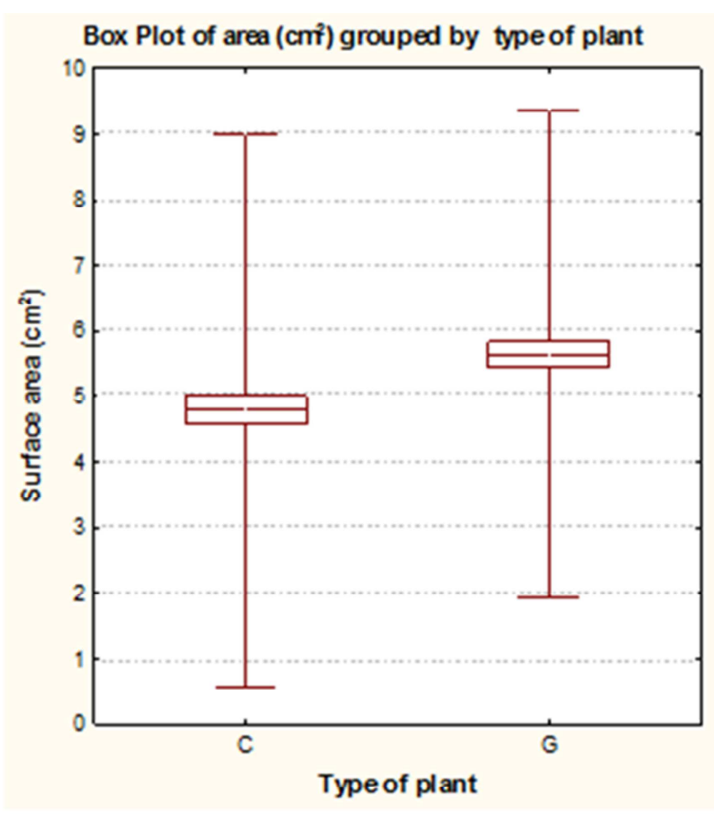

(b)

Figure 2. Comparison of the average, minimum and maximum values of the leaf area under the effect of salt according to the origin (a) and the type of plant (b). 
Table 1. Analysis of the variance of leaf area, sugar content and proline content of stressed and unstressed olive trees.

\begin{tabular}{lllllllll}
\hline & Origin effect $(\mathbf{F 1})$ & Plant effect $(\mathbf{F} 2)$ & Stress effect $(\mathbf{F 3})$ & $\mathbf{F 1}$ *F2 & F2*F3 & F1*F3 & F1*F2*F3 \\
\hline Leaf area & 0,000 & 0,000 & 0,43 & 0,000 & 0,99 & 0,70 & 0,023 \\
Sugar content & 0,000 & 0,68 & 0,000 & 0,000 & 0,047 & 0,000 & 0,000 \\
Proline content & 0,001 & 0,425 & 0,000 & 0,218 & 0,047 & 0,000 & 0,001 \\
\hline
\end{tabular}

However, the comparison of the mean, minimum and maximum values shows that the genotypes of Algerian origin have higher values (average $=5.98 \mathrm{~cm}^{2}$, minimum $=1.68$ $\mathrm{cm}^{2}$ and maximum $=10.36 \mathrm{~cm}^{2}$ ) than those of Spanish origin (average $=4.44 \mathrm{~cm}^{2}$, minimum $=1.20 \mathrm{~cm}^{2}$ and maximum $=$ $8.10 \mathrm{~cm}^{2}$ ). (Figure 2a).

Plants derived from cuttings have the average value of the plants grafted on oleaster. The minimum value is $4.44 \mathrm{~cm}^{2}$ for grafted plants and $4.78 \mathrm{~cm}^{2}$ for cuttings; the maximum is $8.10 \mathrm{~cm}^{2}$ for grafted plants and $10.36 \mathrm{~cm}^{2}$ for plants from cuttings. (Figure 2b).

Soluble sugar content

The analysis of the variance of this parameter (Table 1) clearly reveals that the soluble sugar content of all genotypes studied is highly dependent on origin $(p=0.000)$, stress ( $p=$ $0.000)$ as well as for all interactions $(p=0.000)$ except by the type of plant $(\mathrm{p}=0.68)$ and the "type of plant / treatment" interaction (threshold of the bit error rate of 5\%).

After 20 weeks of stress, all the plants reacted in the same way by accumulating large quantities of soluble sugars (figure 3) which are sometimes twice the quantity contained in the leaves of control plants.

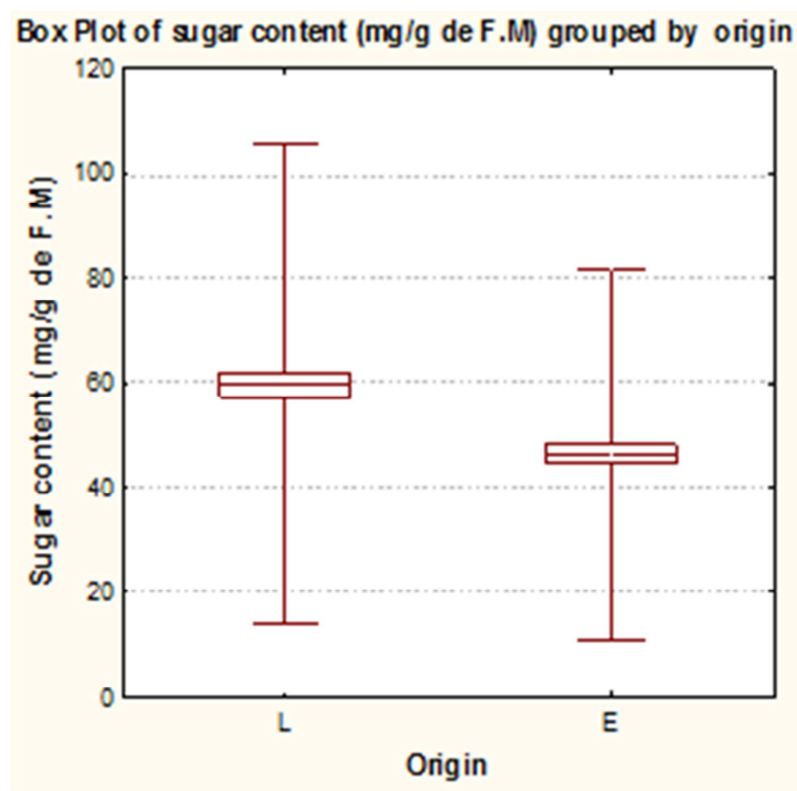

(a)
In fact, in the presence of salt, the same average value of $53 \mathrm{mg} / \mathrm{g}$ of FM in cuttings and grafted on oleaster against values of $9 \mathrm{mg} / \mathrm{g}$ FM in the cuttings control is observed, and $9 \mathrm{mg} / \mathrm{g}$ FM in transplant recipients (Figure 4a). In addition, there were also increases in the soluble sugar content of 60 $\mathrm{mg} / \mathrm{g}$ of FM in local varieties and $45 \mathrm{mg} / \mathrm{g}$ of FM in varieties introduced (Figure 4b).

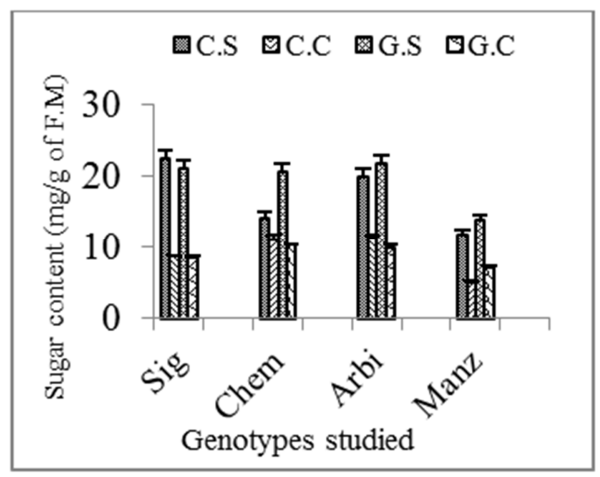

Figure 3. Sugar contents of the studied olive plants SC: stressed cuttings, CC: Cutting Control, SG: Stressed Graft, GC: Grafted Control).

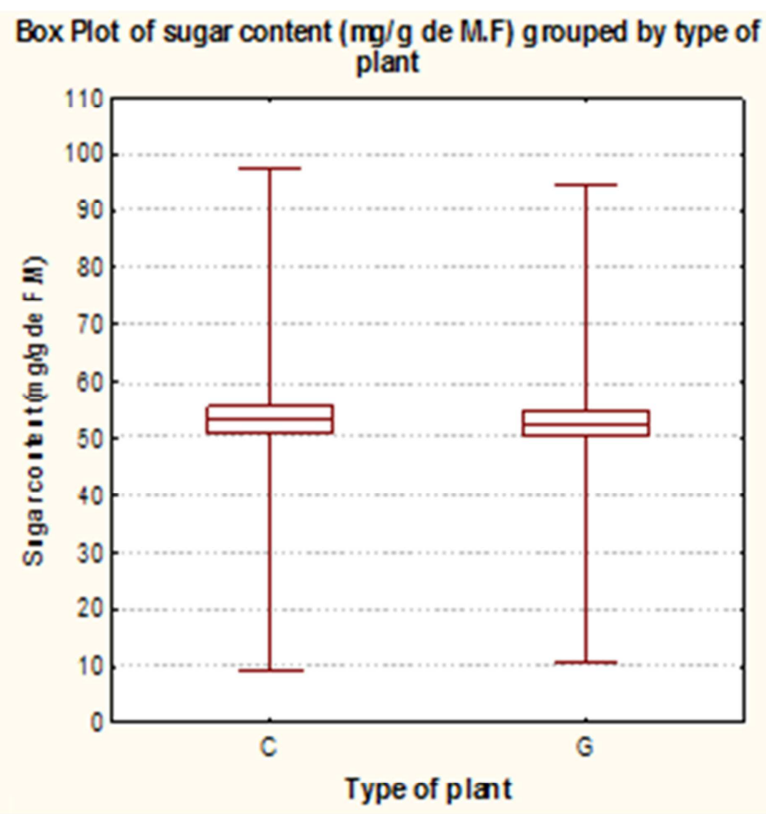

(b)

Figure 4. Comparison of the average, minimum and maximum values of the sugar content under the effect of salt (a). According to the origin (b) and the type of plant (c).

\section{Proline content}

The accumulation of salt in the substrate has led to an increase in the proline content in the leaves (Figure 5)

The analysis of the results obtained of the proline content after the 20 weeks of stress (Table 1) shows that it depends on the variety $(\mathrm{p}=0.013)$, interactions "type of plant / treatment" $(p=0.047)$, "variety / treatment" $(p=0.007)$ and strongly dependent on the "variety / plant type / treatment" 
interaction with $\mathrm{p}=0 \%$.

As regards the proline content, the local and Spanish varieties

Respectively record the following values:

For local varieties, an average value of $21 \mu \mathrm{g} / \mathrm{g}$ of FM, a minimum of $12 \mu \mathrm{g} / \mathrm{g}$ of FM and a maximum of $101 \mu \mathrm{g} / \mathrm{g}$ of FM. For those of Spanish origin, an average value of 25 $\mu \mathrm{g} / \mathrm{g}$ of MF, a minimum of $14 \mu \mathrm{g} / \mathrm{g}$ of F.M and a maximum of $44 \mu \mathrm{g} / \mathrm{g}$ of MF. (Figure $6 \mathrm{a})$.

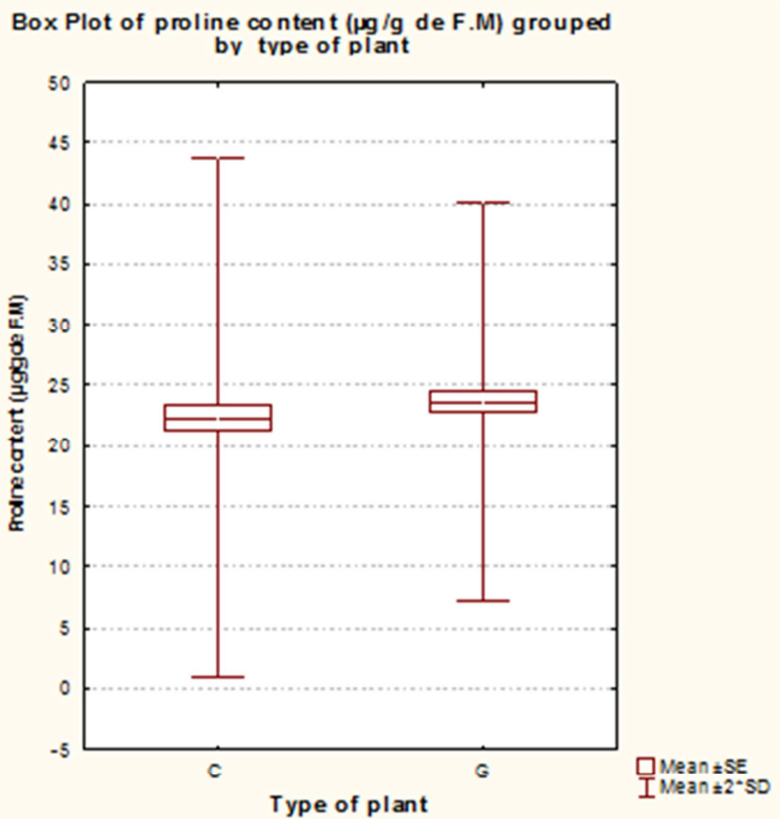

(a)

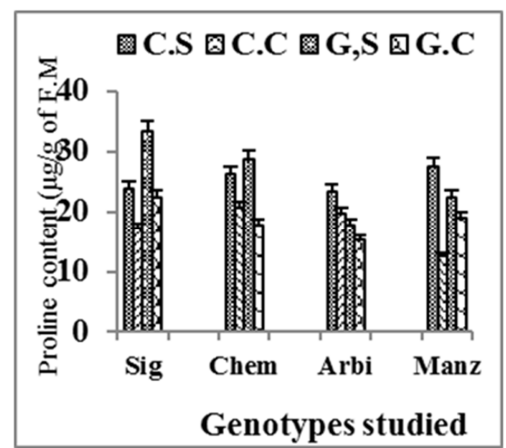

Figure 5. Proline contents of the studied olive plants (SC: stressed cuttings, CC: Cutting Control, SG: Stressed Graft, GC: Grafted Control).

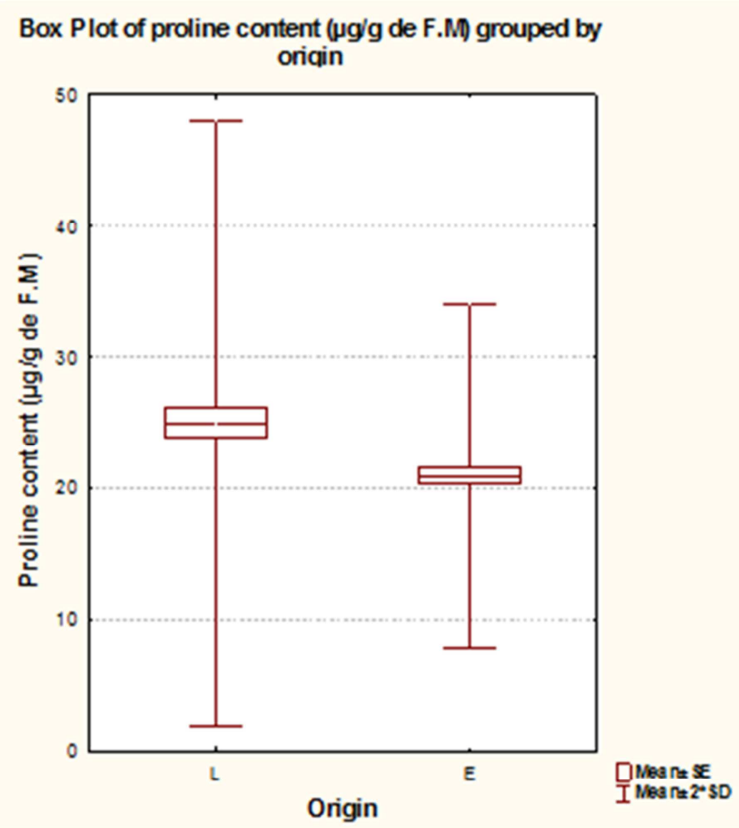

(b)

Figure 6. Comparison of the average, minimum and maximum values of the proline content under the effect of salt. (a). According to the origin (b) and the type of plant.

In fact, in the presence of salt, the leaves have an average proline content of $12 \mu \mathrm{g} / \mathrm{g}$ FM for cuttings and $24 \mu \mathrm{g} / \mathrm{g}$ FM for grafted plants, in addition to a minimum of $22 \mu \mathrm{g} / \mathrm{g}$ of FM. in cuttings and a maximum of $101 \mu \mathrm{g} / \mathrm{g}$ of FM against $24 \mu \mathrm{g} / \mathrm{g}$ of minimum MF and $56 \mu \mathrm{g} / \mathrm{g}$ of MF in oleatral plants (Figure 6b).

\section{Discussion}

Our study focuses on the irrigation of young olive plants of Algerian and Spanish origin with salt water at $100 \mathrm{mM} . \mathrm{l}^{-}$ ${ }^{1} \mathrm{NaCl}$, about $6 \mathrm{~g} / 1$ of soluble salts for 20 weeks. This allowed us to determined some characteristics of the morpho-biochemical behavior of this species under salt stress.

Morphological behavior, expressed as a leaf area, was not very sensitive to the applied treatment $(\mathrm{r}=-0.086)$. In fact, the decreased in leaf area was between $1 \mathrm{~cm}^{2}$ and 1.5 $\mathrm{cm}^{2}$.

Table 2. Correlation affect between salinity and the leaf morpho-biochemical parameters.

\begin{tabular}{|c|c|c|c|c|c|c|}
\hline Variable & Origin & Type of plant & Salinity & Leaf area & Sugar content & Proline content \\
\hline Origin & 1.000 & & & & & \\
\hline Type of plant & 0.000 & 1.000 & & & & \\
\hline Salinity & 0.000 & 0.000 & 1.000 & 1.000 & & \\
\hline Leaf area & $-0.384 *$ & 0.015 & -0.086 & $0.368 *$ & 1.000 & \\
\hline Sugar content & $0.312^{*}$ & $0.211 *$ & $+0.752 * * *$ & $0.265^{*}$ & 0.032 & \\
\hline Proline content & $0.211^{*}$ & $0.611^{* *}$ & $+0.331 *$ & 0.008 & 0.012 & $0.456^{*}$ \\
\hline
\end{tabular}

$* * * \mathrm{p}<0.001, * * \mathrm{p}<0.01, * \mathrm{p}<0.05$ and $\mathrm{p}>0.05$ insignificant. 
This parameter is one of the criteria for evaluating abiotic stress tolerance. The immediate response to salt stress results in reduced leaf area [13] and reduced vegetative growth, expressed as reduced leaf area. Leaf surface is usually the first reaction of glycophytes exposed to salt stress [14].

The decreased in leaf area was considered as a form of adaptation to salt stress, reducing water loss through transpiration and the accumulation of soluble sugars and proline act in the case of olive to better to preserve the photosynthetic potentialities [15].

Indeed, the decrease of the leaf area is presented as a strategy developed by the olive tree, to mitigate the limitation of the availability of water under the conditions of salt stress, these results confirm those of [16].

The shortage in the leaf growth rate after an increase in salinity is mainly due to the osmotic effect of salt around the roots. These effects cause water loss from leaf cells, but this loss of volume and turgidity does not last long due to the osmotic adjustment mechanism, despite this, the elongation rate of the cell is reduced.

The olive plants adjust their transpiration through reductions in leaf area, with significant genetic variability of these reductions. Leaf area is an important determinant of transpiration. One of the first reactions of plants to the water deficit caused by salinity is to reduce the leaf area through different mechanisms. There is significant genetic variability in the degree of growth response during stress [17, 18].

The varieties of local origin and those grafted on oysters show higher average values than the varieties of origin introduced and those resulting from the cutting. This was confirmed by the analysis results of the correlation matrix between the variety and the leaf area $(\mathrm{p}=-0.384$, see table 02).

After 20 weeks of brackish irrigation at $100 \mathrm{mM} \mathrm{NaCl}$, the accumulation of sugars is very important in all stressed genotypes compared to control plants. However, the accumulation of this osmolyte is very important in the leaves of the Algerian genotypes (Sigoise and Chemlal) compared to those of Spanish origin (Arbiquina and Manzanilla). Indeed, there is a positive and highly significant correlation (Table 2$)(\mathrm{r}=+0.752 * * *)$ between

The considerable increase in sugar levels has been known for a long time, as a phenomenon of resistance in plants subjected to different types of stress, which has been verified in adult eucalyptus trees under different water stress by [19; $20]$ in celery under salt stress and in the argan tree by [21].

Several physiological studies have shown that the accumulation of sugars and polyols, mainly following hydrolysis of starch], was stimulated by salt stress in different plant species [22-28].

Regarding the proline osmolyte, although its accumulation is not as important as the sugars; the results obtained reveal an increase in its content in the leaves of stressed genotypes compared to control plants.

In addition, the accumulation of proline is greater in the leaves of local varieties (Sigoise and Chemlal) and grafted on oleaster than in the leaves of the introduced varieties (Arbiquina and Manzanilla) and plants derived from cuttings.

In saline environments, plants adjust their cellular content osmotically by synthesizing amino acids such as proline [29]. proline accumulation is one of the adaptation strategies triggered by the plant in the face of environmental constraints [30].

Under stress, proline plays several functions: osmotic adjustment [31], osmoprotective, [32, 33], antioxidant [34, 35], regulator of cytosolic acidity [36], carbon and nitrogen reserve after the disappearance of stress [37], stress marker [38] and adaptability [39].

The proline concentration is higher in the tolerant genotypes than in the salt stress sensitive genotypes [40-42].

In fact, our results show that genotypes of Algerian origin have average values of proline osmolyte accumulation higher than genotypes of Spanish origin, and that plants transplanted on oleaster also record higher values than seedlings from cuttings. The accumulation of proline is associated with a better stress tolerance, which allowed us to deduce that local plants behave towards salinity and that the same principle is observed for plants grafted on oleaster compared to plants in cuttings [43].

\section{Conclusion}

The morpho-biochemical parameters of the leaf, retained in this study, demonstrate that they are closely involved in salt stress resistance. However, the diversity of salt effects on plants offers a wide range of morphological, physiological, biochemical, anatomical and nutritional criteria that can be used as a basis for large scale rapid selection tests. The immediate response to salt stress is a reduction in leaf area and a reduction in vegetative growth, expressed as reduced leaf area. The surface of the leaves is usually the first reaction of glycophytes exposed to salt stress.

The application of salt water at a concentration of $100 \mathrm{mM}-1-1 \mathrm{NaCl}$; for 20 weeks resulted in a reduction in leaf area, but relatively less compared to other plants subjected to the same salt stress. This characteristic can be attributed to the osmotic adjustment induced by the accumulation of osmolytes (sugars and proline) in the leaves of stressed plants.

In fact, in the Mediterranean regions, physiological drought (due to excessive salinity) is often chronic, leading to a decrease in photosynthesis. Then our results showed that all the varieties studied under the effect of the salinity accumulated sugars and proline compared to those of the normal conditions, which reduces the loss of water by the leaves. This may explain the resistance of the olive tree in general and especially the genotypes studied, which have retained their leaves for the duration of 20 weeks of brackish water irrigation.

The results obtained in this study allow us to deduce that the olive tree is a salinity-resistant plant, characteristic of 
arid and semi-arid zones and that it thus constitutes a promising alternative to improve the productivity of marginalized lands.

\section{References}

[1] Loussert R, Brousse G (1978): L'olivier. Systématique et classification botanique. G. P. Maisonneuve et La rose, Paris.

[2] Rozema, J., Flowers, T., 2008. Crops for a salinized world. Science 322, 1478-1480.

[3] Abdel Latef, A. A., 2010. Changes of antioxidative enzymes in salinity tolerance among different wheat cultivars. Cereal Res. Comm. 38, 43-55.

[4] Pasternak, D., Malach, Y. D., 1994. Crop irrigation with saline water. In: essarakli Mo (Ed.), Handbook of Plant and Crop Stress. Marcel Dekker, New York, p.599-622.

[5] Villa-Castorena, M., Ulery, A. L., Catalan-Valencia, E. A., Remmenga, M. D., 2003. Salinity and nitrogen rate effects on the growth and yield of Chile pepper plants. Soil. Sci. Soc. Am. J. 67, 1781-1789.

[6] Kinet M., F. Z Benrebiha, S. Bouzid, S. Lailcahar \& P. Dupuit., 1998.Reseau Atriplex. Atelier biotechnologies et écologie pour une sécurité alimentaire accrue en régions arides et semi arides. Cahiers Agricultures, Vol.7, $\mathrm{N}^{\circ} 6,505509$.

[7] Hoagland, D. R., Arnon, D. I. (1938). The water culture method for growing plants without soil. University of California, Agricultural experimental station Circular, 347, 139.

[8] Gate, P., (1995): Ecophysiologie du blé. Ed. Lavoisier, PARIS; tech. et doc., pp 244-245 (429 Pages).

[9] Shields, R. et Burnett, W. (1960). Determination of protein bound carbohydrate in serum by a just modified anthrone method. Anal. Chem., 32: 885-886.

[10] Rekika D. (1997). Identification des caractères physiologiques liés au rendement en condition de sécheresse chez le blé dur. Thèse Doctorat, ENSA Montpellier, 102p.

[11] Troll W.; and Lindsley J. (1955): A photometric method for the determination of proline. J. Biol. Che., 215, 655-660.

[12] Leport. L., 1992. Accumulation de proline associée aux contraintes environnementales et à la floraison chez le colza (Brassica napus L). Thèse D'état. 156 p. Rennes.

[13] Wang Y., Nil N., 2000. Changes in chlorophyll, ribulose biphosphate carboxylase oxygenase, glycine betaine content, photosynthesis and transpiration in Amaranthus tricolor leaves during salt stress. J. Hortic. Sci. Biotechnol, 75: 623-627.

[14] Munns, R., A. J. Richard, A. Lauchli (2006): Approaches to increasing the salt tolerance of wheat and other cereals. Journal of Experimental Botany, Vol. 57, No. 5, pp. 10251043.

[15] Sarda X., Vansuyt G., Tousch D., Casse-Delbart F., Lamaze T., 1993, Les signaux racinaires de la régulation stomatique, Tolérance à la sécheresse des céréales en zones méditerranéenne. Diversité génétique et amélioration variétale, Éditions Inra, Paris, pp. 75-79.
[16] Steduto P., Albrizio R., Giorio P. and Sorrentino G., 2000. Gas exchange response and stomatal and non-stomatal limitations to carbon assimilation of sunflower under salinity 144 (3) 243255.

[17] Zhang, J. L., Shi, H., (2013). Physiological and molecular mechanisms of plant salt tolerance. Photosynthesis Research, 115, 1-22. https://doi.org/10.1007/s11120-013-9813-6.

[18] Raymond J., Janet L., Siefert, Christopher R., Staples and Robert E., 2004: The Natural History of Nitrogen Fixation Mol. Biol. Evol., 21: p541-554.

[19] Chunyang L, Kaiyun W (2003): Differences in drought responses of three contrasting Eucalyptus microtheca F. Muell. populations. Uni of Helsinki. Finland. Forest Ecology and Management 179: $377-385$.

[20] Noiraud N., Delrot S. AND Lemoin R. (2000): The sucrose transporter of celery. Identification and expression during salt stress 1. Plant physiol. Volum 122, Pp 1447-1456.

[21] Bouzoubaâ. Z., El Mousadik. A et Benlahcen Y. (2006). Variation in amounts of epicuticular waxes on leaves of argania spinosa (L). Skeels. Acta Bot. Gallica 153(2), 167177.

[22] Hoekstra F. A., Golovina E. A. and Butinik J. 2001. Mechanism of plant desiccation tolerance. Trends Plant Sci. 6: 431-438.

[23] Phillips, J. R., Oliver, M. J., et Bartels, D. 2002. Molecular genetics of desiccation and tolerant systems. Dans Desiccation and survival in plants: Drying without dying. Sous la direction de M. Black et H. Pritchard. CAB International, Mol. Gen. Genet. p. 319-341.

[24] Gilmour SJ, Sebolt AM, Salazar MP, Everard JD, Thomashow MF (2000): Overexpression of the Arabidopsis CBF3 transcriptional activator mimics multiple biochemical changes associated with cold acclimation. Plant Physiology., 124: $1854-1865$.

[25] Streeter, J. G., Lohnes, D. G., and Fioritto, R. J. 2001. Pattern of pinitol accu-mulation in soybean plants and relationships to drought tolerance. Plant CellEnviron. 24: 429-438.

[26] Taji T, Ohsumi C, Iuchi S, Seki M, Kasuga M, Kobayashi M, Yamaguchi-Shinozaki K, Shinozaki K. (2002): Important roles of drought- and cold-inducible genes for galactinol synthase in stress tolerance in Arabidopsis thaliana. The Plant Journal.; 29-417-426.

[27] Bartels, D., Sunkar, R. (2005). Drought and Salt Tolerance in Plants. Critical Reviews in Plant Sciences, 24, 23-58.

[28] Majumder A. L., Chatterjee A., Ghosh Dastidar K. \& Majee M. (2010) Diversification and evolution of L-myo-inositol 1phosphate synthase. FEBS Letters 53, 3-10.

[29] Hare PD, Cress WA, Staden V (2002): Dissection the roles of osmolyte accumulation during stress. Plant Cell and Environment; 21: 535-53.

[30] Ashraf, M. and T. McNeilly. 2004. Salinity tolerance in Brassica oilseeds. Crit. Rev. Plant Sci., 23(2): 157-174.

[31] Voetberg G, Sharp RE (1991): Growth of the maize primary root at low water potentials. III. Role of increased proline deposition in osmotic adjustment. Plant physiol 96: 11251130 . 
[32] Moradshahi, A., Eskandari, B. S., and Kholdebarin, B. 2004: Some physiological reponses of canola (Brassica napus L.) to water deficit stress under laboratory conditions Indian J. Sci. Technol., Transaction A. 28 (Al): 43-50.

[33] Kishor P. B. K, Sangam S, Amrutha R. N, Laxmi P. S, Naidu K. R, Rao K. R. S. S, Rao S, Reddy K. J, Theriappan P, Sreenivasula N. 2005: Regulation of proline biosynthesis, degradation, uptake and transport in higher plants: its implications in plant growth and abiotic stress tolerance. Curr. Sci.; 88: 424-438.

[34] Sharma SS., Dietz K. J. (2006): The significance of amino acids and amino acidderived molecules in plant responses and adaptation to heavy metal stress. J Exp Bot.; 57, 711-26.

[35] Eliane Cristina Gruszka Vendruscolo, IvanSchuster, MarcosPileggi, Carlos Alberto Scapim, Hugo Bruno Correa Molinari, Celso Jamil Marur, and Luis Gonzaga Esteves Vieira. (2007): Stress-induced synthesis of proline confers tolerance to water in transgenic wheat.journal of plant physiology.164, 1367-1376.

[36] Sivakumar G, Yu KW, Hahn EJ, Paek KY (2005) Optimization of organic nutrients for ginseng hairy roots production in large-scale bioreactors. Current Sci 89: 641-649.

[37] Kala S, Godar AK. 2011. Effect of moisture stress on leaf total proteins, proline and free amino acid content in commercial cultivars of ziziphus mauritiana. J. Sci. Res., 55: 65-69.

[38] Chaib G., Hazmoune T. et Benlaribi M. (2008). Impact de stress hydrique sur le test proline autant qu'indicateur à la biodiversité de blé dur. Annales de l'INRGREF, Actes des Journées Scientifiques de l'INRGREF, « La biodiversité dans les aires Protégées » Hammamet, Tunisie, 11-13 Novembre 2008. Numéro Spécial (12), 732-746.

[39] Din, J., Khan, U., Ali, I., and Gurmani, R. A.(2011). Physiological and agronomic response of Canola varieties to drought stress. The Journal of Animal and Plant Sciences 2011, 21(1), 78-82.

[40] Garcia A., CA. Rizzo, J. Uddin, SL. Bartos, D. Senadhira, TJ. Flowers, AR. Yeo.(1997):. Sodium and potassium transport to the xylem are inherited independently in rice, and the mechanism of sodium: Potassium selectivity differs between rice and wheat. Plant Cell Environ., 20: 1167-1174.

[41] Benhassaini, H. Fetati, A.; Hocine, A. K.; Belkhodja, M. (2012): Effet du stress salin sur la croissance, l'accumulation de la proline et des sucres solubles sur des plantules portegreffe de pistacia atlantica desf. subsp. Atlantica. Vol. 16, $\mathrm{N}^{\circ} 2 / 2012$.

[42] Ben nja riheb, 2014: Effet d'un stress salin sur la teneur en polymères pariétaux dans les feuilles de luzerne (Medicago sativacv Gabès) et sur la distribution dans les cellules de transfert des fines nervures. Thèse de doctorat, Biosciences de l'Environnement et de la Santé, Universités de Limoges et Carthage. P: 52-53.

[43] Kirti PB, Hadi S, Chopra VL (1991): Seed transmission of salt tolerance in regenerants of Brassica junceaselected in vitro. Cruciferae Newsletter. 1991; 85: 14-15. 